\title{
Composition of fatty acids and tocopherols in peels, seeds and leaves of Sea buckthorn
}

\author{
Zuzana Burčováa, František Kreps ${ }^{\mathrm{a}}$, Štefan Schmidt ${ }^{\mathrm{a}}$, Michal Jablonský $\tilde{y}^{\mathrm{b}}$, \\ Aleš Ház ${ }^{b}$, Alexandra Sládkováb ${ }^{\text {, Igor Šrurina }}{ }^{b}$ \\ ${ }^{a}$ Department of Food Science and Technology; Faculty of Chemical and Food Technology, \\ Slovak University of Technology in Bratislava, Radlinského 9, 81237 Bratislava, Slovak Republic \\ ${ }^{b}$ Department of Wood, Pulp and Paper; Faculty of Chemical and Food Technology, \\ Slovak University of Technology in Bratislava, Radlinského 9, 81237 Bratislava, Slovak Republic \\ z.burcova@gmail.com
}

\begin{abstract}
Peels, seeds and leaves of the Sea buckthorn were extracted by methanol and chloroform and characterized in terms of the fatty acids (FA) and tocopherol composition. All morphological parts of Sea buckthorn contained these biologically active compounds useful in medicine, pharmacology, human nutrition and cosmetics. The highest amount of $\alpha$-tocopherol was found in peels $\left(1103 \mathrm{mg} \mathrm{kg}^{-1}\right)$. The lowest content of $\alpha$-tocopherol was found in leaves $\left(659 \mathrm{mg} \mathrm{kg}^{-1}\right)$. Delta-tocopherol was found in higher amount in peels $1757 \mathrm{mg} \mathrm{kg}^{-1}$. Seeds contained $95 \mathrm{mg} \mathrm{kg}^{-1}$ of delta-tocopherols. Gamma-tocopherol was found in seeds $\left(459 \mathrm{mg} \mathrm{kg}^{-1}\right)$, peels $\left(188 \mathrm{mg} \mathrm{kg}^{-1}\right)$ and in leaves $\left(587 \mathrm{mg} \mathrm{kg}^{-1}\right)$. $\beta$-tocopherol was present only in seeds $\left(171 \mathrm{mg} \mathrm{kg}^{-1}\right)$. Unsaturated fatty acids were dominant in all morphological parts of Sea buckthorn. The highest amounts of unsaturated fatty acids (92 rel. \%) were determined in seeds. Dominant fatty acids of seeds were linoleic acid (37\%), $\alpha$-linolenic acid (30\%) and vaccenic acid (20\%). Leaves were rich in $\alpha$-linolenic acid (51\%). Dominant fatty acids of peels were oleic acid (16\%), palmitic acid (33\%) and palmitoleic acid (29\%).
\end{abstract}

Keywords: Sea buckthorn, extraction, fatty acid, tocopherol, antioxidants

$$
\begin{aligned}
& \text { Abbreviations: } \\
& \text { FA fatty acid } \\
& \text { FFA free fatty acid }
\end{aligned}
$$

conjugated linoleic acid

gas chromatography - flame ionization detector

\section{Introduction}

Sea buckthorn (Hippophae rhamnoides) is about 6 meters high tree belonging to the family Elaeg. naceae. It is characterized by thorny branches, yellow flowers and orange fruits that are only on female trees. This tree has come from the area of China, Mongolia or Nepal (Li et al., 2003). Sea buckthorn is currently cultivated throughout the world. It is an ideal plant for land suffering from erosion. It grows in the temperature range from $-43^{\circ} \mathrm{C}$ to $40^{\circ} \mathrm{C}$, and tolerates well the dry seasons. However, irrigation is necessary in areas with average annual rainfall lower than $400 \mathrm{~mm}$. Sea buckthorn has been used in traditional Chinese medicine, because it is good source of large number of bioactive substances like vitamins (A, C, E, K, riboflavin, folic acid), carotenoids, phytosterols, organic acids, polyunsaturated fatty acids and some essential amino acids (Pintea et al., 2005; Beveridge et al., 1999). Currently, Sea buckthorn has a high pharmacological value, because it has antioxidant, immunomodulatory, anti-atherogenic, anti-stress, hepatoprotective, radioprotective and tissue repair effects (Geetha et al., 2009; Goel et al., 2002).

All parts of sea buckthorn contain biologically active substances. Fruits are rich in carotenoids, tocopherols, tocotrienols, essential polyunsaturated fatty acids, which are known to have significant anti-bacterial, anti-atherogenic and cardioprotective activities (Ting et al., 2011). Fruits of Sea buckthorn contain $13.7 \%$ of saturated (like palmitic acid) and $86.3 \%$ of several unsaturated fatty acids like oleic acid (omega-9), palmitoleic acid (omega-7), linoleic acid (omega-6), and linolenic acid (omega-3) (Yang and Kallio, 2005). Major fatty acids of Sea buckthorn fruits are palmitoleic acid (47.8 \%) and palmitic acid (29.3\%). Major fatty acids in the seeds of Sea buckthorn are oleic acid $(32.8 \%)$, palmitic acid (26.3 \%) and linoleic acid $(21.7 \%)$ (Cakir et al., 2004). The acidity of the fruit can be ascribed to the high content of vitamin C (1683-1840 $\mathrm{mg} \mathrm{kg}^{-1}$ ) (Arimboor et al., 2006). The total tocopherol content in fruits of Sea buckthorn is around $260.4-173.8 \mathrm{mg} \mathrm{kg}^{-1}$. The main isomer of tocopherol is $\alpha$-tocopherol (260.4-540.1 $\mathrm{mg} \mathrm{kg} \mathrm{kg}^{-1}$ ), then $\gamma$-tocopherol $\left(35.6 \mathrm{mg} \mathrm{kg}^{-1}\right)$ and $\delta$-tocopherol $\left(702.8 \mathrm{mg} \mathrm{kg}^{-1}\right)$, while $\beta$-tocopherol occurs in trace amounts. Content of tocopherol isomers is influenced by cultivar, climatic condition and ripening stage (Andersson et al., 2008).

Leaves are rich in phenolic compounds including flavonoids, phenolic acid, quercetin-3-O-galacto- 
side, quercetin-3-O-glucoside, kaempferol and isorhamnetin (Pietta et al., 2000; Michel et al., 2012; Upadhyay et al., 2010).

Branches of Sea buckthorn tree contain phenolic compounds like catechin, gallocatechin, epigallocatechin and tritepenoids like ursolic acid, which have anti-inflammatory effects in mice (Yasukawa et al., 2009).

The hydro-alcoholic extract of Sea buckthorn has antioxidant and neuroprotective effect to the human neuroblastoma cell line-IMR32, because cytotoxicity of hydrogen peroxide was reduced (Shivapriya et al., 2015). Aqueous and hydro-alcoholic extracts of Sea buckthorn have cytoprotective activity against hydrogen peroxide and hypoxanthine-xanthine oxidase-induced damage to BHK21 cell line (Upadhyay et al., 2010). Extract from leaves of Sea buckthorn showed growth inhibiting effect against Bacillus cereus, Pseudomonas aeruginosa, Staphylococcus aureus and Enterococcus faecalis (Upadhyay et al., 2010), and it had also significant anti-inflammatory activity (Ganju et al., 2004).

\section{Experimental}

\section{Materials and methods}

In this experiment seeds, peels, leaves of Sea buckthorn (domestic production, Northern Slovakia) and commercially available Sea buckthorn-tea, which consisted of dried fruits of Sea buckthorn (BIO Tvrdošovce) were used. Used chemicals were of analytical grade (Lachema-Czechia, and Mikrochem, Centralchem-Slovakia). Some solvents, such as n-hexane, i-propanol, methanol was of HPLC or UV spectral purity and were purchased from Sigma Aldrich (Slovakia) and VWR (Austria). Chemicals used for HPLC, GC-FID, GC-MS analyses were of analytical grade (90-99 \%), and were purchased from Sigma Aldrich and Merck (Czechia, Slovakia). Standards of $\alpha$-tocopherol, $\beta$-tocopherol, $\gamma$-tocopherol and $\delta$-tocopherol were purchased from Sigma Aldrich, Slovakia.

\section{Preparation of samples}

The samples of plant parts were collected in midAugust in 2015 (Northern Slovakia). The seeds, peels and leaves of Sea buckthorn were dried at room temperature $\left(25^{\circ} \mathrm{C}\right)$ for one week in the dark. The moisture content of the dried Sea buckthorn parts was $6.20 \%, 6.15 \%$ and $6.75 \%$ for peel, seeds and leaves, and respectively. Peel, seeds and Sea buckthorn tea were homogenized by blender ETA 1-012 (ETA a.s., Slovakia). Leaves of Sea buckthorn were homogenized by hammer mill KL 02-06 (SlovSETRA, s.r.o., Slovakia) and sorted for the size $1.8-4 \mathrm{~mm}$.

\section{Determination of moisture}

Content of moisture in seeds, leaves and peals after drying process was analysed by the Moisture Analyzer MAC 50/NH (Radwag). Standard mode was used as a drying mode. Standard mode is the most frequently used of all drying modes. It enables accurate determination of moisture content in dried sample. The end of the drying process was set by auto switch off mode, where the criterion is loss in mass (less than $1 \mathrm{mg}$ ) in a defined time interval. The drying temperature was $105^{\circ} \mathrm{C}$, according to Príbela et al. (1987).

\section{Determination of lipid content}

\section{Folch extraction}

Lipids were obtained from plant parts of Sea buckthorn by extracting $20 \mathrm{~g}$ of sample according to Folch et al., (1957). Peel, seeds, leaves and Sea buckthorn tea were mixed after homogenization with chloroform and methanol in ratio 2:1 during $20 \mathrm{~min}$ in an orbital shaker at room temperature. Then the extracts were centrifuged to recover the liquid phase. This phase was washed with water to separate the two phases (chloroform and methanol phase). The lower (chloroform) phase, containing lipids, was evaporated under vacuum in a rotary evaporator and stored under nitrogen in freeze $\left(-22{ }^{\circ} \mathrm{C}\right)$ until analysis.

\section{Soxhlet extraction}

Lipids of Sea buckthorn peel were obtained also by Soxhlet extraction according to Ilavská et al. (Ilavská, 1990). $10 \mathrm{~g}$ of peel sample and solvent $n$-hexan were used to the extraction. Time of extraction was 4 hours. After this time, the solvent was evaporated and lipid fraction was stored under the nitrogen atmosphere in freezer $\left(-22^{\circ} \mathrm{C}\right)$ until analysis.

\section{Saponification of lipid fractions}

Saponification was carried out as previously reported by ČSN EN ISO 3596-1. Weight of sample for saponification was $5 \mathrm{~g} \pm 0,1 \mathrm{~g}$. To the saponification of Sea buckthorn parts extracts was used $50 \mathrm{~cm}^{3}\left(1 \mathrm{~mol} \mathrm{dm}^{-3}\right)$ ethanolic KOH. Saponification was carried out at boiling point of ethanolic $\mathrm{KOH}$ and under the reflux. After $1 \mathrm{~h}, 100 \mathrm{ml}$ of water was added.

\section{Determination of unsaponifiable matter}

Extracted samples were saponified according to the AOAC Official Method 933.08. After removing of the solvent using a vacuum rotary evaporator, yields were stored in the freezer $\left(-20^{\circ} \mathrm{C}\right.$ ) until further analysis. 


\section{Analysis of fatty acids}

Fatty acid composition of Sea buckthorn extracts used in the study in the form of methyl esters (FAME) was determined by GC-FID as previously reported by Christopherson et al. (1969). Fatty acid composition was analysed by the gas chromatograph GC-7890 (Agilent, USA) with a capillary column DB-23 $(60 \mathrm{~m} \times 1 \mathrm{~mm} \times 00: 25$ 12:25 film microns). The conditions of analysis were as follows: FAME and heptane (1 \%) was used for the injection $(1 \mathrm{ml})$, split $(10: 1)$ at $230{ }^{\circ} \mathrm{C}$; carrier gas flow rate $(\mathrm{H}) 16.4 \mathrm{~cm}^{3} \mathrm{~min}^{-1} ; 220 \mathrm{kPa}$; oven temperature set to $150{ }^{\circ} \mathrm{C}$, the temperature program was used. Temperature rose at $5^{\circ} \mathrm{C} \min ^{-1}$ to $170{ }^{\circ} \mathrm{C}$, $6{ }^{\circ} \mathrm{C} \mathrm{min}^{-1}$ at $220^{\circ} \mathrm{C}$ and was maintained for another $6 \mathrm{~min}$. Next was the rate of $6^{\circ} \mathrm{C} \mathrm{min}^{-1}$ at $220^{\circ} \mathrm{C}$ for $1 \mathrm{~min}$ and $30^{\circ} \mathrm{C} \mathrm{min} \mathrm{m}^{-1}$ at $240{ }^{\circ} \mathrm{C}$ for 10 minutes. The hydrogen flow to the FID and the air flow rate were $40 \mathrm{~cm}^{3} \mathrm{~min}^{-1}$ and $450 \mathrm{~cm}^{3} \mathrm{~min}^{-1}$, respectively.

\section{Analysis of tocopherols}

The qualitative and quantitative analysis of tocopherols in Sea buckthorn plant parts extracts was performed by HPLC-UV (1100 series, Agilent, USA) (AOCS Ce 8-89, 1993). Contents of tocopherols were determined at one wavelengths $292 \mathrm{~nm}\left(\lambda_{\max }\right.$ for the $\alpha$-tocopherol). The plant parts extracts were dissolved in n-hexane to the concentration $0.1 \mathrm{~g} \mathrm{~cm}^{-3}$. Dissolved samples were injected $(20 \mu \mathrm{l})$ into the column Nucleodur $100 \mathrm{Si}$, $250 \times 4 \mathrm{~mm}$, particle size $5 \mu \mathrm{m}$ (Macherey-Nagel Ltd., Germany). The mobile phase contains n-hexane and i-propanol in ratio 99:1 and the flow rate

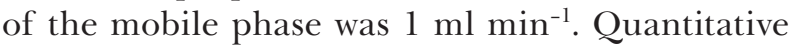
analysis of tocopherols was performed by calibration curves of $\alpha$-, $\beta$-, $\gamma$ - and $\delta$-tocopherols (Sigma Aldrich). Contents of tocopherol were expressed in $\mathrm{mg} \mathrm{kg}^{-1}$.

\section{Results and discussion}

\section{Oil content in Sea buckthorn}

Table 1 presents the contents of oils obtained from various morphological parts of Sea buckthorn by two types of extraction (Folch and Soxhlet extraction). The oil content in seeds was $72.83 \mathrm{~g} \mathrm{~kg}^{-1}$. Higher content of oil was detected in peel $\left(153.81 \mathrm{~g} \mathrm{~kg}^{-1}\right)$ and in tea from Sea buckthorn containing dried fruit $\left(155.03 \mathrm{~g} \mathrm{~kg}^{-1}\right)$. Leaves display lower content of oil. It is only $42.30 \mathrm{~g} \mathrm{~kg}^{-1}$. Higher content of oil from peel was obtained by Folch extraction in comparison with Soxhlet extraction. After Folch extraction of peel $153.81 \mathrm{~g} \mathrm{~kg}^{-1}$ of oil was obtained, whereas only $104.15 \mathrm{~g} \mathrm{~kg}^{-1}$ of oil was obtained after Soxhlet extraction of peel. This difference may be caused by higher extraction force of chloroform in comparison with n-hexane. Our results are similar as are reported in study Kallio et al., (2002), who found the oil content in seed between 26 and $101 \mathrm{~g} \mathrm{~kg}^{-1}$ depending on the variety of Sea buckthorn. Oil content (in \%) of peel is similar as is reported previously in study Yang et al., (2001a)

Tab. 1. Oil content in various morphological parts of Sea buckthorn.

\begin{tabular}{lcc}
\hline Sample & $\begin{array}{c}\text { Oil content } \\
{\left[\mathrm{g} \mathrm{kg}^{-1}\right]}\end{array}$ & Oil content $[\%]$ \\
\hline \multicolumn{3}{c}{ Folch extraction } \\
\hline Sea buckthorn tea & 155.03 & 15.50 \\
Seeds & 72.83 & 7.28 \\
Leaves & 42.30 & 4.23 \\
Peels & 153.81 & 15.3 \\
\hline \multicolumn{3}{c}{ Soxhlet extraction } \\
\hline Peels & 104.15 & 10.41
\end{tabular}

\section{Determination of unsaponifiable matter}

The results of unsaponifiable matter are presented in Table 2. We determined the high amounts of unsaponifiable matter in peels and in leaves of Sea buckthorn $16.91 \%$ and $11.5 \%$, in respectively. It is caused by chemical structure of peels and leaves. They include phytosterols and tocopherols that protect the fruit before oxidation (Yang, 2001b; Yang, 2002).

Tab. 2. Unsaponifiable matter of Sea buckthorn morphological parts.

\begin{tabular}{lc}
\hline Sample & Unsaponifiable matter [\%] \\
\hline Sea buckthorn tea & 10.46 \\
Seeds & 5.42 \\
Leaves & 11.5 \\
Peels & 16.91 \\
\hline
\end{tabular}

\section{Content of tocopherols}

Amounts of tocopherols isolated from different parts of Sea buckthorn are presented in the Fig. 1. The total tocopherol content varied from $1246.4 \mathrm{mg} \mathrm{kg}^{-1}$ to $3047 \mathrm{mg} \mathrm{kg}^{-1}$. According to the Zadernowski et al. (2003), the total tocopherol content in whole berries of Sea buckthorn was 1014 and $1283 \mathrm{mg} \mathrm{kg}^{-1}$ of oil. Andersson et al. (2008) reported that the total tocopherol content varied from 260.4 to $1173.8 \mathrm{mg} \mathrm{kg}^{-1}$. In other studies, Beveridge, et al. (1999) and Zhang et al. (1989) confirmed the total tocopherol content from 610 to $1130 \mathrm{mg} \mathrm{kg}^{-1}$ in seed oil, from 1620 to $2550 \mathrm{mg} \mathrm{kg}^{-1}$ in juice oil. The predominant tocopherol was $\alpha$-tocopherol. Contents of $\alpha$-tocopherol varied from $659.0 \mathrm{mg} \mathrm{kg}{ }^{-1}$ to $1102.9 \mathrm{mg} \mathrm{kg}^{-1}$. The 
highest amount of $\alpha$-tocopherol was found in peels $1102.9 \mathrm{mg} \mathrm{kg}^{-1}$. On the other hand, the lowest content of $\alpha$-tocopherol was present in leaves $659.0 \mathrm{mg} \mathrm{kg}$. Lower amount $354.1 \mathrm{mg} \mathrm{kg}^{-1}$ of $\alpha$-tocopherol in leaves was found in study Go'rnas et al., (2016). High amount of $\alpha$-tocopherol was found in Sea buckthorn tea $\left(1081.1 \mathrm{mg} \mathrm{kg}^{-1}\right)$, which may be ascribed to its composition (seeds and peels). Deltatocopherol was found in higher amount in peels $\left(1757.0 \mathrm{mg} \mathrm{kg}^{-1}\right)$. It has higher antioxidant effectiveness in vivo systems than $\alpha$-, $\beta$-, or $\gamma$-tocopherol. Delta-tocopherol has a protective effect against FA oxidation of Sea buckthorn fruits. Content of $\delta$-tocopherols in seeds was $94.7 \mathrm{mg} \mathrm{kg}^{-1}$. It was found also in large amounts $\left(414.3 \mathrm{mg} \mathrm{kg}^{-1}\right)$ in Sea buckthorn tea. Gamma-tocopherol was found in all parts of Sea buckthorn plant we analyzed, and its content varied from $160.7 \mathrm{mg} \mathrm{kg}^{-1}$ for Sea buckthorn tea, to $587.0 \mathrm{mg} \mathrm{kg}^{-1}$ for leaves. Seeds and peels contain $458.5 \mathrm{mg} \mathrm{kg}^{-1}$ and $188.0 \mathrm{mg} \mathrm{kg}^{-1}$ of $\gamma$-tocopherol, respectively. In this study, we found $\beta$-tocophe rol in seeds $\left(170.7 \mathrm{mg} \mathrm{kg}^{-1}\right)$ and in tea $\left(171.4 \mathrm{mg} \mathrm{kg}^{-1}\right)$ only. In studies of Andersson et al. (2008) and Zadernowski et al. (2003), $\beta$-tocopherol was not found in morphological parts of Sea buckthorn. On the other hand, Go'rnas et al., (2016) reported that leaves contain $24.3 \mathrm{mg} \mathrm{kg}^{-1}$ of $\beta$-tocopherol.

\section{Composition of fatty acids}

Fatty acids compositions of morphological parts of Sea buckthorn are summarized in the Table 3 . Unsaturated fatty acids are predominant in all of its morphological parts. Higher amounts of unsaturated fatty acids $(91.5 \%, \mathrm{w} / \mathrm{w})$ were determined in seeds extract. The predominant unsaturated fatty acids of seeds were linoleic acid $37.3 \%$, $\alpha$-linolenic acid $29.9 \%$ and vaccenic acid $20.3 \%$. These values are in part in agreement with those of Kallio et al. (2002) who found 35-38\% of linoleic acid, $29.0 \%$ of $\alpha$-linolenic acid and $2 \%$ of vaccenic acid in the seed oil. Small differences can be caused by variations in cultivation, climate conditions, or different harvesting time. According to Zadernowski et al. (2003), the composition of Sea buckthorn fruits depends on the harvesting time. We confirmed their data that leaves are rich in $\alpha$-linolenic acid (51.1\%). The peels of Sea buckthorn contained the lowest content of unsaturated fatty acids among morphological parts analyzed (60\%) with palmitoleic acid (28.6\%) and oleic acid (16.1\%) as predominant species. Palmitic acid was the predominant saturated fatty acid (32.9\% of $40 \%$ total). According to Gardner et al. (1989), saturated fatty acids are oxidized more slowly than unsaturated fatty acids. When oxidation occurs slowly, unsaturated fatty acids of fruits are longer stable. This can explain the low content of unsaturated fatty acids in the surface layer of fruits (peels) and their higher content in seeds.

Most valuable fatty acids of Sea buckthorn are palmitoleic acid, linoleic acid, and $\alpha$-linolenic acid. Palmitoleic acid is the predominant fatty acid in human skin. It has antimicrobial properties and it is effective in blocking the adherence of pathogenic strains of Candida albicans to porcine stratum corneum. Palmitoleic acid may be used in medicine and pharmacology, for the treatment of secondary gram-positive bacterial infections, or as a grampositive bacteria antimicrobial in wound dressings (Wille et al., 2003). Further, it decreases the content of cholesterol and triacylglycerol in the liver (Matthan et al., 2010). Conjugated linoleic acid (CLA) is a group of geometric and positional isomers of

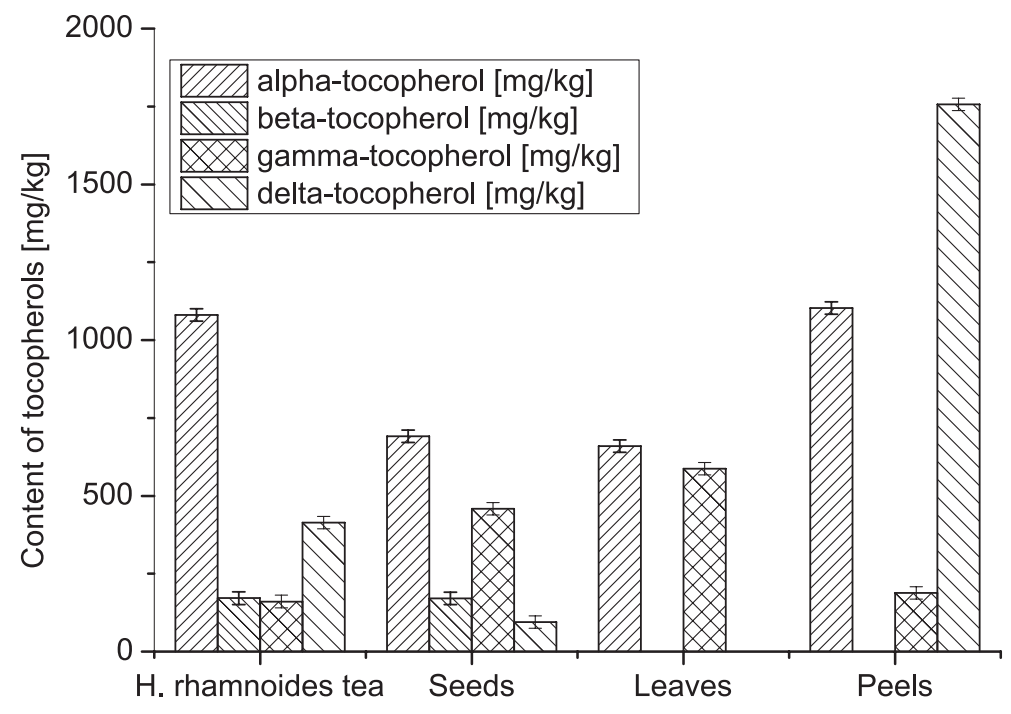

Fig. 1. Types and contents of tocopherols in Sea buckthorn. 
Tab. 3. Fatty acids composition of different morphological parts of Sea buckthorn.

\begin{tabular}{lcccc}
\hline Fatty acids & Sea buckthorn tea [\% rel.] & Seeds [\% rel.] & Leaves [\% rel.] & Peels [\% rel.] \\
\hline myristic & 0.1 & - & 1.6 & 0.4 \\
palmitic & 31.3 & 7.7 & 19.6 & 32.9 \\
palmitoleic & 16.2 & 0.9 & 1.5 & 28.6 \\
stearic & 1.4 & 0.3 & 3.2 & 7.8 \\
oleic & 31.6 & 2.8 & 1.6 & 16.1 \\
cis-vaccenic & 7.3 & 20.3 & 9.5 & 6.5 \\
linoleic & 6.7 & 37.3 & 51.1 & 8.8 \\
a-linolenic & 4.9 & 29.9 & - & 4.4 \\
gadoleic & 0.2 & 0.2 & 3.2 & - \\
behenic & - & 0.1 & 29.3 & 40.0 \\
\hline saturated & 33.1 & 8.5 & 70.7 & 60.0 \\
unsaturated & 66.9 & 91.5 & & \\
\hline
\end{tabular}

linoleic acid (Chin et al., 1994). Conjugated linoleic acid has the anticarcinogenic effects in various cancer models. Conjugated linoleic acid decreased mammary tumor incidence, inhibited epidermal tumors and reduced skin tumor incidence. In recent studies, CLA decreased the amount of body fat, and had good impact on metabolism of rats, because CLA-supplemented rats had significantly lower blood glucose, plasma insulin, circulating free fatty acids and lower density lipoprotein (LDL) cholesterol (Whigham et al., 2000).

\section{Conclusions}

The present study shows that all studied parts of Sea buckthorn contain interesting and biologically active compounds. Sea buckthorn is a valuable source of antioxidants like $\alpha$-, $\beta$-, $\gamma$ - and $\delta$-tocopherols. We found higher amounts of $\alpha$-tocopherols in peels and in Sea buckthorn tea. In contrast to other authors, we succeeded to find that seed contain $\beta$-tocopherol. Further we found, that $\delta$-tocopherol was detected in higher amount in peels of Sea buckthorn. Deltatocopherol has higher antioxidative effectiveness in in vivo systems than $\alpha$-, $\beta$-, or $\gamma$-tocopherols. Deltatocopherol has a protective effect against fatty acid oxidation of Sea buckthorn fruits. In this study, we investigated fatty acid composition in peels, seeds, leaves and Sea buckthorn tea. We found that unsaturated biologically active fatty acids were mainly in Sea buckthorn seeds. Higher amounts of palmitoleic acid were found in peels of Sea buckthorn. It is known that palmitoleic acid is present in human skin layer. Due to these properties Sea buckthorn preparations can be added to the food or cosmetic products in order to increase their biological and nutritional values.

\section{Acknowledgements}

This work was supported by the Slovak Scientific Grant Agency contract no. VEGA 1/0860/13 and VEGA 1/0353/16, and by the Slovak Research and Development Agency under contracts no. APVV 0850-11, and no. APVV 0393-14. The authors would like to thank the STU Grant scheme for Support of Excellent Teams of Young Researchers (contracts no. 1601 and 1608), for financial assistance. This article was created thanks for the support of researchers who work in the OP Research and Development for the project "National Center for Research and Application of renewable energy sources", ITMS 26240120016, and ITMS 26240120028, and for the project "Competence center for new materials, advanced technologies and Energy" ITMS 26240220073, and Science, and Technology Park STU (ITMS 26240220084), co-financed from the European Regional Development Fund.

\section{References}

Anderson SC, Rumpunen KR, Johansson E, Olsson ME (2008) J. Agric. Food Chem, 56, 6701-6706.

AOCS official method Ce 8 - 89. 1993. 5 p.

Arimboor R, Venugopalan VV, Sarinkumar K, Arumughan C, Sawhney R Ch (2006) J Sci Food Agric, 86: 2345-2353.

Beveridge T, Li TSC, Oomah BD (1999) Journal of Agriculture and Food Chemistry 47, 3480-3488.

Cakir A 2004. Biochemical Systematics and Ecology, 32: 809-816.

ČSN EN ISO 3596-1: Metody zkoušení tuků a olejů - Stanovení nezmýdelnitelného podílu - Cást 1 : Metoda diethyleterové extrakce (Referenční metoda), 04/2001.

Folch J (1957) J Biol Chem. 226: 497-509.

Ganjua TL, Padwada Y, Singha R, Karana D, Chandaa S, Choprab MK, Bhatnagarb P, Kashyapb R, Sawhneya RC (2005) 5: 1675-1684. 
Gardner HW (1989) Free Radical Biology and Medicine, 7: $65-86$

Geetha S, Sairam M, Sharma SK, Ilavazhagan G, Banerjee PK, Sawhne RC (2009) Journal of Medicinal Food 12: $151-158$.

Go’rnas' P, Šné E, Siger A, Seglina D (2016) Saudi Journal of Biological Sciences, 23: 512-516.

Goel HC, Prasad J, Singh S, Sagar R, Kumar I, Sinha AK (2002) Phytomedicine, 9: 135-143.

Chin SF, Storkson JM, Albright KJ, Cook ME, Pariza MW (1994) J. Nutr., 12: 2344-2349.

Christopherson SW, Glass R (1969) Journal of Dairy Science, 52: 1289-1290.

Ilavská E. Schmidt Š. Hojerová J (1990) 283 p.

Kallio H, Yang B, Peippo P, Tahvonen R, Pan R (2002) J. Agric. Food Chem. 50: 3004-3009.

Li TSC, Beverige HJ (2003) ISBN 0-660-19007-9. 133 p.

Matthan NR, Dillard A, Lecker JL, Ip B, Lichtenstein AH (2010) American Society for Nutrition. J. Nutr., 140: 215-221.

Michel T, Destandau E, Floch GL, Lucchesi ME, Elfakir C (2012) Food Chemistry, 131: 754-760.

Pietta PG (2000) Journal of Natural Products, 63: $1035-1042$.

Pintea A, Varga A, Stepnowski P, Socaciu C, Cule M, Diehl HA (2005) Phytochemical Analysis, 16: 188-195.

Príbela A (1987) Analýza potravín. Cvičenie, Edičné stredisko SVŠT Bratislava, 1. Ed., 394 p., ISBN 85383-87.
Rao KS (2007) Neurosciences, 145: 1330-1340.

Shivapriya S, Ilango K, Dubey GP (2015) Saudi Journal of Biological Sciences, 22: 645-650.

Ting HCH, Hsu YW, Tsai CH F, Lu FJ, Chou MCH, Chen WK (2011) Food Chemistry, 125: 652-659.

Upadhyay NK, Kumar MSY, Gupta A (2010) Food and Chemical Toxicology, 48: 3443-3448.

Whigham LD, Cook ME, Atkinson RL (2000) Pharmacological Research, 42: 503-510.

Wille JJ, Kydonieus A (2003) Skin Pharmacol Appl Skin Physiol 16: 176-187.

Yang B, Kalio H (2001a) J. Agric. Food Chem. 49: 1939-1947.

Yang B, Kallio H (2002) Trends in Food Science \& Technology, 13: 160-167.

Yang B, Kallio HP (2005) Amultipurpose Wonder Plant, Vol. 2. Daya Publishing House, New Delhi, India, 70-97.

Yang B, Karlsson RM, Oksman PH, Kallio HP (2001b) J. Agric. Food Chem, 49: 5620-5629.

Yasukawa K, Kitanaka S, Kawata K, Goto K (2009) Fitoterapia, 80: 164-167.

Zadernowskia R, Naczkb M, Amarowiczc R (2003) Journal of the American Oil Chemists' Society, 80: 55-58.

Zhang W, Yang J, Duo J, Ren B, Guo J (1989) Proceedings of International Symposium on Sea Buckthorn (Sea buckthorn L.) China, October 19-23, 129-132. 